\title{
PERFORMANCE OF INSPECTORATE IN SUPERVISION OF GOVERNMENT ADMINISTRATION IN BURU SELATAN REGENCY
}

\author{
Hendry Selanno, and Marno Wance \\ Fakultas Ilmu Sosial dan Ilmu Politik, Universitas Pattimura, Jln.M.Putuhena, Poka, Kota Ambon \\ E-mail: endox_selanno@yahoo.com,marno.wance@fisip.unpatti.ac.id
}

\begin{abstract}
This article investigated Performance of the Inspectorate in Supervision of Government Administration in Buru Selatan Regency. The type of study used was descriptive research. This would provide a factual depiction regarding the application of Inspectorate function of Buru Selatan Regency. This study aimed to analyze the performance of the Inspectorate in Supervision of Government Administration in Buru Selatan Regency. This study suggested that the application of supervision either perceived from the inspection, examination to investigation, in fact it had not been effectively worked due to the fact that inaccuracy in supervising and inaccurate aberration data were discovered for apparatus inspector in the office of Inspectorate. The factors affecting the performance of inspection function for government administration in Buru Selatan regency included the skilled apparatus officers having knowledge in the field of work of which they should tackle and facilities and infrastructure assisting the performance of inspection performed by the Inspectorate Office in Buru Selatan regency. The result suggested that the knowledge in the field of work was still low. It was suggested to implement the inspection planning functions for the purpose of supporting the speed in collecting data and accurate data/information presentation to date will support the reporting of any aberration arising in regional government administration, engage the officers in Human Resources development and the fulfillment of supporting facilitates and infrastructure.
\end{abstract}

Key words: Performance; contol; Inspectorate

\section{KINERJA INSPEKTORAT DALAM PENGAWASAN PENYELENGGARAAN PEMERINTAHAN KABUPATEN BURU SELATAN}

\begin{abstract}
ABSTRAK. Artikel ini membahas tentang Kinerja Inspektorat Dalam Pengawasan Penyelenggaraan Pemerintahan Kabupaten Buru Selatan. Tipe penelitian yang digunakan dalam penelitian ini adalah tipe deskriptif. Tipe penelitian ini akan memberikan gambaran faktual mengenai pelaksanaan fungsi Inspektorat Kabupaten Buru Selatan.Tujuan penelitian untuk menganalisis kinerja Inspektorat Dalam Pengawasan Penyelenggaraan Pemerintahan Kabupaten Buru Selatan dan untuk menganalisis faktor-faktor yang mempengaruhi efektivitas fungsi pengawasan kinerja Inspektorat Kabupaten Buru Selatan. Penelitian ini menghasilkan bahwa pelaksanaan pengawasan baik dilihat dari pemeriksaan, pengujian hingga penyelidikan, ternyata belum efektif, hal ini disebabkan karena adanya ketidaktepatan waktu dalam melakukan pengawasan, belum akuratnya data penyimpangan yang ditemukan untuk aparatur pengawas di kantor Inspektorat. Faktor yang mempengaruhi pelaksanaan penyelenggaraan fungsi pengawasan terhadap penyelenggaraan pemerintahan kabupaten Buru Selatan adalah meliputi aparatur petugas yang memiliki skill, pengetahuan di bidang pekerjaan yang ditangani dan selain itu tersedianya sarana dan prasarana yang mendukung pelaksanaan pengawasan yang dilakukan oleh Kantor Inspektorat di kabupaten Buru Selatan. Hasilnya bahwa pengetahuan dibidang pekerjaan masih minim, serta sarana dan prasarana yang mendukung juga sangat minim. Disarankan agar perlunya diterapkan fungsi perencanaan program pengawasan, hal ini bertujuan untuk dapat menunjang kecepatan dalam memperoleh data dan selain itu penyajian data/ informasi yang akurat selama ini akan menunjang pelaporan terhadap penyimpangan yang terjadi dalam penyelenggaraan pemerintahan daerah, mengikutsertakan pegawai dalam pengembangan Sumber Daya Manusia dan pemenuhan sarana dan prasarana pendukung.
\end{abstract}

Kata kunci: Kinerja; Pengawasan; Inspektorat

\section{INTRODUCTION}

In case of improving efficiency and effectivity of regional Government performance, all parties should participate particularly from the apparatus who shall serve in the Government. An effective government is a pressing need especially in the reformation era nowadays focused on providing services to society. This is identified by claims from society regarding the support for embodying clear and authoritative Government apparatus so as to perform their duties and functions orderly in accordance with the applicable provisions. Any claims from society might be brought on by any improper practice done generally by Government apparatus as well as specifically by regional Government. Aberration often occurring among the regional Government apparatus shall be as a result of ineffective inspection performed by the existing organizations within the body of regional government itself.

The legal basis that can be used as a reference in the implementation of supervision is to refer to Law No. 4 of 1990 jo 23 of 2014 concerning local. Government which is strengthened by 
Government Regulation No. 20 of 2001 concerning guidance and supervision over the administration of regional government, Presidential Decree No. 74 of 2001 concerning procedures for supervision of the implementation of Regional Government and Ministerial Decree No. 41 of 2001 concerning repressive supervision of regional policies.

Authorities or leaders need to supervise, because without supervision will result in deviations. That is why effective supervision needs to be carried out, especially relating to the main tasks of Government and development, this aims to support the realization of a clean and authoritative Government, and to realize it, it is necessary to apply the oversight function to Government and development performance.

South Buru Regency Inspectorate which has a function in supervising the performance of regional government, where one of the things to be achieved is to prevent irregularities in the implementation of regional government management. Then the other function is to conduct supervision, inspection, assessment and investigation of two principles, namely: Provincial Regional Oversight Agency as a vertical form, and the Regent as a source of acceptance of duties, so as to support the implementation of supervisory personnel, supervisory or supervisory supervisors are used, as needed. (Manullang, 2006).

Inspectorate Secretariat of Buru Selatan Regency should be striving to implement and stabilize the application of functional inspection for any existing component within the organization of which scope of work to consider and take any duty and responsibility in the best possible way so as to provide the contribution value in performing the duties as best as they could. Thus it shall be expected to be able to control any type of work activity performed conforming to the duty and responsibility given. Any disputes arose in the government administration in Buru Selatan regency including: 1) Internal support from SKPD (Local Government Working Unit) provides convoluted data and information to internal auditor, document requirements necessary for inspection reference including LK, LKPD and IKK in each SKPD is less available, 2) Follow-up for the settlement of inspection or audit results in each SPD remains lower which might be brought on by leaders of whose commitment in making a change are still lower. For instance, cash management in expenditure treasurer has not been orderly implemented and unavailability of SOP as one of the reference standards in performance assessment immediately for each SKPD, 3) No strict sanctions imposed by the leaders for working negligence in every SKPD in case of following-up the findings and recommendations, 4)
Availability of Auditors resources from the amount and competency standpoint remains limited so that the supervision duties shall be performed maximally, 5) Limited Budget availability in engaging employees to participate in position training of auditor functional and technical assistance as well as supervision courses. (Results of interview and observations conducted by the author)

In accordance with the above explanation regarding several issues of performance of Inspectorate in Buru Selatan Regency emerged from empirical evidence through observations, the formulation of the problem that the author obtained is: How is the Inspectorate's Performance in Supervision of the Implementation of the South Buru Regency Government?

Performance is an outcome of a process (Suryadi, 2010) or the degree of success individually or entirely within a specified period of time in performing the duties (Veitzal \& Basri, 2005) either in quality or quantity (Mangkunegara, 2001). Therefore, according to Ashwatappa, performance shall be consistently measured from the aspect of result instead of the effort put forth by an individual i.e how an individu may fulfill work demands well (Hosmani \& Shambhushankar, 2014).

Hasibuan (within Hadari Nawawi, 2006) confirmed that performance is work outcomes accomplished by an individual in performing her/his duties imposed in accordance with skills, experience, sincerity and time, or a person's achievement under test conditions etc. (Keban, 2008).

According to Yunus (2012), Dhermawan et.al (2012) and Pebrianti (2013) performance (work achievement) is work outcomes in quality and quantity aspects accomplished by an employee in performing his/her duties under the imposed responsibility.

Performance is results note produced (resulted) or the function of a certain work or activities for a specfied period of time (Sudarmono, 2009). Performance was etymologically stemmed from the word performance (Aries \& Baskoro, 2012).

Organization achievement shall be successfully obtained based on the employees' performance (Shakeel and Lodhi, 2015). According to Shahzadi (2014), performance of employees shall be perceived as what they do and what they do not do, employees' performance involves output quality and quantity, presence in site, accommodative and beneficial behavior as well as output accuracy. Their performance might be affected by motivation due to the fact that when they are motivated, then they shall perform the works with more initiative so as to 
improve the performance (Azar and Shafighi, 2013), as motivation constitutes interior courage resulting an individu in deciding to take measure and motivation is affected by biological, intellectual, social and emotional factors (Chaudhary N \& Sharma, B, 2012).

According to Hood (in Wargadinata, 2017), the performance of public organizations that are considered lagging behind private organizations is used as an excuse by the government to implement performance measurement policies for public organizations. Governments in many countries hope that performance measurement makes public organizations more efficient, effective and accountable.

According to Riordan (in Christi, 2010), indicators in performance include 1) punctuality, a certain work type requires the attendance in work settlement in accordance with the designated time. 2) Quantity, a person might complete his/her work within a designated period of time. 3) Quality, every employee should recognize and settle relevant problems as well as has positive work attitude in the site. Moreover, the result of research conducted by Hammed and Waheed, (2011) in improving the employees' performance, it requires employee development, skills improvement, employee training, individual orientation, behavior and attitude orientation, pursuant to Nassari (2013), Einaga et. al (2013), Farooq et. al (2011), Tabassi (2011), Dysvik and Kuvaas (2008), Rogers (2003), Sultana et. al (2012), and Asim (2013) stating the same.

Dwiyanto (in Averus A \& Pitono Andi, 2018) reveals that the performance of public organizations can be assessed in five measures, namely (1) Productivity (2)Quality of service(3) Responsiveness (4) Responsibility (5) Accountability

From the definition of performance above, it may be concluded that performance is a work output accomplished from a set of attitude under the purpose in a specified period of time.

Low performance of an employee will affect the organizational performance. On the other words, employee's performance may reflect organizational performance. Organizational performance is an aggregation or accumulation of the performance of all organizational units, equivalent to the sum up of all people' or individuals' performance working in the company (Payaman, 2011).

According to Bastian (in Hessel, 2005) organizational performance is a description on the level of task implementation achievement in an organization, in order to realize target, purpose, mission and vision of the organization. Company's or organizational performance is the level of purpose or target achievement that must be achieved by the company in a certain period of time (Payaman, 2011).

The term of supervision in English is known as controlling, by which Dale (in Winardi 2000) said that: "the modern concept of control ... provides a historical record of what has happened .... and provides date the enable the ...executive ...to take corrective steps...". It means that controlling is not only seeing something carefully and report the control activity result, but also means to correct and align it so as to achieve the purpose as planned. More (in Winardi 2000) stated that: "there' many a slip between giving works, assignment to men and carrying them out. Get reports of what is being done, compare it with what ought to be done, and do something about it if the two aren't the same".

Thus, control in essence is an act of comparing between the result in reality (dassein) and the result desired (dassolen). It is because there are often aberrations on both, so control task is correcting the aberrations.

Control is the fourth managerial function after planning, organizing, and directing. As one of the managerial functions, control mechanism in an organization is indeed necessary. The implementation of a plan or program without being assisted by a good and continuous control system will surely cause low or even non achievement of the predetermined target and purpose.

Control is all activities to reassure and guarantee that the task/work has been performed according to the predetermined plan. The policy specified and order (rules) given (Siagian, 2003).

To make sure that all works given by a leader to his/her subordinates can run according to the plan, the leader must have the ability to guide, demand, lead, motivate, drive the organization, build a good communication network, good insights source, as well as bring his/her followers toward the target according to the regulations, time, and plan (Kartono, 2002).

According to S.P. Siagian control is a crucial step as well as a managerial organic function because through control it is observed whether the things specified are performed well or not.

(Kartono, 2002) provides a definition of control that in general the followers can cooperate well toward the common target and purpose achievement of a control organization to measure the work outcome and avoid aberrations and perform corrective actions on the aberrations if necessary. (Siagian, 2003) said that control is an observation process of the overall implementation of an organization to assure that all works in progress are according to the predetermined plan. 
Therefore, control must be considered as an information system, since the speed and determination of corrective action as the result of control process depends on the type of information received. (Fattah, 2014). According to (Kansil, 2002) control is vital to warrant that the implementation of government control policy is an endeavor to assure:

a. Harmony between government task administration by regional and central governments.

b. Smooth government administration effectively and efficiently.

Control according to (Handoko, 1998) is defined as a process to assure that organization and managerial purposes are achieved. It is associated with the methods in making the activities as planned. This study aimed to formulate an effective organizational model for regional authorities in organizing governmental affairs which were their authority. (Martini, 2019)

From the above points, it is evident that control is performed to evaluate the implementation of work task on the basis of a certain assessment standard and perform corrective actions if necessary. Hence, Kontz and O'Donnel (in Simbolon, 2004) said that control is an assessment and correction for the work implementation performed by subordinates aiming to attain assurance ensuring that company's purposes and plans are used to achieve them.

The essence of control is to avoid as early as possible aberrations, waste, misappropriation, obstacles, mistakes, failures in achieving target and implementing organizational tasks. According to Sondang P Siagian, control is an observation process of the overall organizational activities to ensure that all efforts of work in progress are according to the predetermined plan.

In terms of the relationship between central and regional, control is a "bond" of unity, so that the autonomy pendulum of freedom is not moving too far so as to reduce even threat unity (unitary): “ “.. if local autonomy is not to produce a state of affairs bordering on ancrhy, it must be subordinated to national interest by means devised to keep its actions within bounds".

If it is related to the control on Government, it can be seen that the general definition of control is still relevant, because: first, in general the target of control on Government is preservation or protection so that state welfare law can run smoothly and also bring Government power as people welfare administration toward a good implementation and still within the power boundary, second, the standard is law regulating material or formal laws (rechmatgheid), as well as the benefits for people welfare (doelmatigheid), third, coordination between actions and standard determined, fourth, in case there are signs of aberration on the standard, a correction must be done through cancelation, recovery on the impact resulted and discipline the doer.

\section{METHOD}

This article is a result of study using qualitative approach. Research basis using case study method is an approach aimed to learn in-depth about the implementation of the function of Inspectorate of Buru Selatan Regency. Case study is a research strategy, empirical review investigating a phenomenon in real life background. Data collection technique was using FGD (Focus Group Discussion), in-depth interview, Literature review and Documentation.

FGD is a discussion group not interview, the interaction between the writer and informant and informant with the study informant. FGD in this study was used as a tool to collect pre-research data aimed to obtain initial data. The number of informants for FGD was 5 people (Head of Inspectorate/Inspector, Secretary Inspectorate, 1 Chief of Inspection Team and 2 Auditors).

In-depth interview is a repetitive face-to-face meeting between writer and the research subjects in order to understand the perspective of the research subjects. The number of informants for interview was 12 people ( 5 of them are the informants for $\mathrm{FGD}$ ).

These 12 informants were consisting of $1 \mathrm{Head}$ of Inspectorate/Inspector of Buru Selatan Regency, 1 Secretary Inspectorate, 1 Chief of Inspection Team, 2 Auditors, 3 SPKD Leaders (Education and culture office, Legal Department of Regional Secretariat, and DPRD Secretary) as well as 4 Employees.

\section{RESULTS AND DISCUSSION}

Inspectorate of Buru Selatan Regency is one of the Regional Work Units under Buru Selatan Regency Government formed based on the Regional Regulation of Buru Selatan Regency Number 04 of 2016 on Formation and Composition of Inspectorate organization of Buru Selatan Regency. With the change on the Inspectorate organizational structure, it shall remove the structural position under District Assistant Inspector. Inspectorate of Buru Selatan Regency is a control element for Regional Government administration led by an Inspector in performing his/her duties in lower position and directly liable to Regent as well as technically and administratively gaining coaching from Regional 
Secretary. The core duty of the Inspector of Buru Selatan Regency is helping Regent in administrating control duty on the implementation of regional government affairs and coaching implementation for village administration.

The Inspectorate of Buru Selatan Regency implemented 3 functions (Regulation of the Minister of Home Affairs Number 64 of 2007 on Organizational Technical Guidelines and Working Procedure of Provincial and Municipal Government Article 13 paragraph (d)) namely:

1. Implementation of Inspection functions of the Inspectorate of Buru Selatan Regency.

2. Implementation of examination functions of the Inspectorate of Buru Selatan Regency.

3. Implementation of investigation functions of the Inspectorate of Buru Selatan Regency.

\section{Implementation of the function of Inspection of the South Buru District Inspectorate.}

Based on the South Buru Regent Regulation No. 52 of 2016 concerning the Principal Job Description, Function and Work Area of the South Buru Regency Inspectorate has the main task of carrying out oversight of the implementation of the affairs and administration of the South Buru Regency. In this connection the South Buru Regency Inspectorate must certainly be able to take corrective action on irregularities committed against the implementation of government affairs and administration in the regions if it is not in accordance with the applicable laws and regulations, as well as providing guidance to all Regional Apparatus Work Units which are within South Buru Regency Government area.

South Buru Regency Inspectorate as an institution that carries out supervision of the implementation of affairs and administration of regional government, is required to be able to play an role as an institution that is able to improve the quality of supervision of the implementation of regional development so that it can realize good governance and clean government with the aim of making a real contribution to increasing prosperity of the people.

Examination begins with the submission of the proposed assignment, then making a program audit, and issuing an Assignment Letter. After the Letter of Duty is issued, supervision is carried out in the field which includes opening conference activities, field inspections, communication of findings, requests for audited responses to supervisory findings, exit conferences and reporting. For auditing and spot check audits, auditing responses are not requested.

1. Assignment Preparation

The main activity at this stage is the gathering of general information about the auditee, to be examined in order to determine the tentative audit objectives or the estimated problems that need attention at the preliminary audit stage. Overall assignment preparation activities include: 1) Issuance of assignments, 2) Notification to Auditors, 3) Collection of general information, 4) Formation of assignment plans and 5) Preparation of audit programs for preliminary audits.

The phasing of the assignment preparation from the research results shows that the inspection is based on the PKPT that has been compiled and the inspection is carried out by the inspection team based on the inspection areas and subsequently the issuance of the assignment letter to each auditor.

The next process is notification to the Auditors, this process is carried out by delivering a notification letter to all regional apparatus organizations (OPD) regarding the schedule of inspection that is attached with PKPT, in addition to submitting the implementation schedule of the inspection it is also informed to all OPD to prepare the data needed in order to collect general information.

The results showed that the readiness of the basic data of the examination and the leadership of the OPD or auditing as an audit target is very important, but not all of the OPD can prepare well.

\section{Inspection Stages}

The results of the study of the assessment of the accuracy of work standards / procedures and the time of the examination, concluded that in carrying out the examination of the implementation of regional government activities are timely but specifically to reach the farthest locations are still an obstacle.

Atthe inspection stage the auditor seeks to obtain cooperation with the Auditor, obtain a more detailed picture of the Audite, as well as gather preliminary evidence and conduct various reviews by taking into account the tentative audit objectives and following the audit steps in the preliminary audit program. The results of the initial evidence gathering and review are used to determine definitive audit objectives in order to plan the next audit procedure. Overall activities carried out by the auditor in this preliminary audit, including: 1) preliminary meetings, 2) field observations, 3) document review, 4) evaluation of internal controls, 5) analytical procedures and 6) preparation of audit / audit report

Based on the results of research on the inspection system, in conducting surveillance it can be concluded that the inspection system that has been carried out by the South Buru Regency Inspectorate is transparent and in accordance with procedures, with 
the reason because in conducting supervision of the performance of the local government, the accuracy of the data obtained in the field is appropriate with a plan and in conducting supervision and can be accounted for, there is good coordination.

\section{Implementation of Data Update on Follow-Up on Examination Results}

In an effort to enforce the oversight function, the follow-up of the supervision report becomes very important because the success or failure of the supervision of the regional government can be seen from the level of compliance of the regional government in carrying out the recommendations of the Government Oversight Official examination results. (Jafar Saidi, 2008) Follow-up on recommendations can be in the form of implementing all or part of these recommendations.

Following up on the results of the supervision report means that the local government has a commitment to correct mistakes and errors in the administration of regional government. Without follow-up, the goal of supervision is not achieved, namely improving performance for the organization and will cause public distrust.

The follow up of the results of this supervision is influenced by various factors, namely the lack of attention of work units that are the object of Oversight, the absence of strict sanctions for the enforcement of disciplinary penalties, political factors, collusion factors and the quality of the results of supervision.

Meetings to update the follow-up data of the results of supervision by the Government Oversight Officer in South Buru Selatan Regency could not be carried out in accordance with the Regulation of the Minister of Home Affairs, which is 2 times a year, but only done once a year, due to limited manpower, time and cost.

\section{Implementation of the South Buru district Inspec- torate testing function}

At this stage an examination is carried out, by gathering more evidence and deeper analysis, in order to strengthen / complete the attributes related to the issues that need attention as identified in the examination / audit. This test implementation activity is also called a follow-up examination / expansion of the test / development of findings.

Based on the results of the assessment regarding the effectiveness of the inspection and its relationship with the oversight function carried out by the Inspectorate Office in South Buru Regency, the subsequent evaluation in carrying out the effectiveness of testing in implementing the supervisory function is especially at the Inspectorate Office in South Buru Regency.

One obstacle faced in conducting testing is inaccurate data, where the data obtained cannot yet be used as a guideline for testing and is valid. So that one of the factors that causes the inaccuracy of information obtained in the field and besides that there are limitations of each party in providing information

It turns out that testing the amount of information obtained is not objective, where testing of the amount of information received is not in accordance with the areas of deviation that often occurs. One of the factors is due to the limited amount of information available in the field and besides the lack of coordination directly involved in conducting supervision of the performance of local government.

\section{Implementation of the investigation function of the South Buru Regency Inspectorate}

Monitoring activities other than inspection and testing are also supported by the implementation of the investigation. Therefore it is necessary to be supported by an assessment of the effectiveness of the implementation of the investigation and its relationship with the local government performance monitoring function.

Based on the results of research that one of the objectives carried out in conducting investigations is to facilitate the investigation of irregularities or abuse of authority either based on the findings of the examination or procurement or information from various parties.

Then seen from the results of the examination regarding the effectiveness of the investigation and its relationship with supervision, it turned out that the implementation of the investigation was not timely. This is due to the slowness of information received in carrying out the examination and testing of each data that is used as an object of supervision. In conducting investigations, investigators, especially at the Inspectorate Office in South Buru Regency, appeared to be still weak based on the areas of irregularities that occurred.

The factors that influence the effectiveness of the supervision performance of South Buru Regency inspectorates are:

1. Supervisory Staff Resources Inspectorate

From the condition of the number of employees in the South Buru Regency Inspectorate environment, it is still not ideal compared to the workload and number of inspection objects handled. Because of these conditions, in the future it will be proposed to increase the number of staff to be able to 
compensate for the increasingly complex workload within the South Buru Regency Inspectorate.

South Buru Regency Inspectorate until 2019 does not have functional staff of the Regional Government Affairs Supervisory Officer (P2UPD), based on the Regulation of the Minister of Administrative Reform and Bureaucratic Reform of the Republic of Indonesia Number 15 of 2009 concerning the Functional Position of the Government Supervisor at the District / District Inspectorate of at most 48 people and Joint Regulation of the Minister of Home Affairs of the Republic of Indonesia and the Head of the State Personnel Agency Number 22 and Number 03 of 2010 concerning Guidelines for Implementing the Functional Position of the Supervisory of Organizing Government Affairs in Regions and Their Credit Numbers.

The South Buru Regency Government, in this case the Inspectorate based on the regulation, the South Buru Regency Inspectorate will propose functional officials of the supervisors of regional government affairs according to their fields and expertise.

Regulation of the Minister of Home Affairs Number 64 of 2007 concerning Technical Guidelines for the Organization and Work Procedures of Provincial, Regency / Regency Inspectorates Chapter III Article 18 states that if the Government Supervisory Functional Position has been determined in accordance with the laws and regulations then the Structural Position under the Assistant Inspectorate is deleted.

Based on the two laws and regulations, an adjustment / inpassing will be made in the Functional Position of the Supervisory of the Implementation of Regional Government Affairs (P2UPD) and the Functional Auditor Position (FAP) at the South Buru Regency Inspectorate, which of course must be confirmed by the Regent's decision, and the implementation instructions are determined by the decision of the head of the BKD and the Training related to the Functional Position of the Supervisory of the Implementation of Regional GovernmentAffairs (P2UPD) and Credit Score, so that it is expected that in carrying out its main tasks and functions the Inspectorate can be more independent, professional and accountable in conducting supervision of supervision of the Regional Work Unit (SKPD) that located in the District Government of South Buru Regency.

2. Facilities and Infrastructure of the Inspectorate In accordance with the results of the study concerning the management of infrastructure both theoretically and empirically in the field that in its implementation there are still constraints / obstacles so that there is a gap between theoretical and empirical. Each dimension has weaknesses, namely:

Planning needs by not coordinating first with the user of goods, minimal input due to lack of communication with employees who need these facilities and impressed in the planning needs are less than optimal so that employees lack respect in addressing the needs of existing facilities.

Procurement of infrastructure is basically both theoretically and empirically almost appropriate and can be accounted for, but after testing results that procurement was not carried out, because when interviewing informants about procurement procedures carried out by self-management through the providers of goods / services, the informant was not aware of any the procurement. Storage of infrastructure based on empirical results is not well organized and well managed, there are still a lot of files that are stacked in one room so it does not facilitate the search for necessary files, management of infrastructure, especially in storage is still not optimal.

Distribution of infrastructure has been done in accordance with employee expectations, this can be seen from the distribution of consumables directly distributed to each employee so that it can be utilized. For other inventory items such as two or four-wheeled vehicles.

The abolition of infrastructure at the South Buru Regency Inspectorate has never been carried out in accordance with applicable regulations, because existing infrastructure is still being utilized and has not been able to replace with new ones.

\section{CONCLUSION}

Based on the results of an analysis of the inspectorate's performance in the implementation of the supervisory function, especially at the Inspectorate Office of South Buru Regency, the Islands, it can be concluded that the implementation of supervision, whether seen from inspection, testing to investigation, has not been effectiveyet. which was found for the supervisory apparatus in the Inspectorate office.

Factors affecting the implementation of the oversight function of the South Buru regency administration include apparatus officers who have the skills, knowledge in the field of work being handled and besides the availability of facilities and infrastructure 
that support the implementation of supervision carried out by the Inspectorate Office in South Buru district.

\section{REFERENCE}

Aries S \& Baskoro. (2012). Pengaruh Motivasi Kerja dan Gaya Kepemimpinan terhadap Disiplin Kerja serta dampaknya pada kinerja karyawan (Studi Kasus pada PT PLN (Persero) APD Semarang. Jurnal Sumber Daya Manusia, 7 (2), 9.

Averus, A. \& Pitono, A. (2018). Pengaruh Pengawasan TerhadapKinerjaPegawaiDalam Meningkatkan Pelayanan Kesehatan di Kota Palu Provinsi Sulawesi Tengah. Sosiohumaniora 19, (2), 8694

Azar, M. S. A. (2013). The Effect of Work Motivation on Employees's Job Performance (Case Study: Employees of Isfahan Islamic Revolution Housing Foundation. International Journal of Academic Research in Business and Social Sciences, 3, (9), 432-445.

Christi. (2010). Impact of Participative Management on Employee Job Satisfaction and Performance in Pakistan. Journal Language in India, 10, (3), 154

Dhermawan, A.A.N Bagus, Sudibya, I Gde Adnyana \& Utama, W. M. (2010). Pengaruh motivasi, Lingkungan Kerja, Kompetensi, dan kompensasi terhadap kepuasan kerja dan kinerja pegawai di lingkungan kantor Dinas Pekerjaan Umum Propinsi Bali. Jurnal Manajemen, Strategi Bisnis dan kewirausahaan. Jurnal Manajemen, Strategi Bisnis Dan Kewirausahaan, 3, (6), 173.

Dysvik, A., \& Kuvaas, B. (2008). The relationship between perceived training oppotunities, work motivation and employee outcome. International Journal of Training and Development, 12, (3), 543

Elnaga, A. \& Imran, A. (2013). The effect of training on employee performance. European Journal of Business and Management, 54.

Farooq, M. \& Khan, M. . (2011). Impact of training and feedback on employee performance. Far East Journal of Psychology and Business, 5, (1), 1187

Fattah Nanang. (2014). Konsep Manajemen Berbasis Sekolah (MBS) dan Dewan Sekolah. Bandung Pustaka Bani Quraisy.
Hammed, A.W. (2011). Employee development and its affect on employee performance: A conceptual framework. International Journal of Humanities and Social. 14, (7), 93

Handoko, T.H. (1998). Manajemen dan Sumber Daya Manusia. Yogyakarta Liberty.

Hosmani A, \& Shambhushankar, B. (2014). Study on Impact of Quality of Work Life on Job Performance amongst Employees of Secunderabad Division of South Central Railway. Research Journal of Management Sciences. 13, (4), 764

Kansil. (2002). Pengantar Ilmu Hukum dan Tata Hukum Indonesia. Balai Pustaka Jakarta.

Keban, Y.T. (2008). Enam Dimensi Strategis Administrasi Publik: Konsep Teori dan Isu. Yogyakarta Gaya Media.

Mangkunegara A.A. (2001). Manajemen Sumber Daya Manusia Alih Bahasa. Salemba Empat.

Martini,A.(2019). Organizational ModelApplication on Local Acency Organizational Struture. Sosiohumaniora, 21, (2), 200-209. https://doi. org/10.24198/sosiohumaniora.v21i2.21780

Manullang. (2006). Dasar-dasar Manajemen. Gajah Mada University Press.

Maringan, M.S. (2004). Dasar-dasar Administrasi dan Manajemen. Jakarta Ghalia Indonesia.

Nassazi, A. (2013). Effect of training on employee performance. Evidence from Uganda. Business Economic and Tourism, University of Applied Sciences.

Nawawi, H. (2006). Evaluasi dan Manajemen Kinerja di Lingkungan Perusahaan dan Industri. Gajah Mada University Press.

Payaman. (2011). Evaluasi Kinerja Sumber Daya Manusia. Salemba Empat.

Pebrianti, T. (2013). Pengaruh disiplin kerja terhadap kinerja pegawai di lingkungan Biro Humas dan Protokol Sekretariat Daerah Propinsi Sumatera Selatan. Jurnal Orasi Bisnis. 9, (3), 21

Rogers, T.T., Pasztor, E.M. \& Kleinpeter, C. . (2003). The Impact of training on worker performance and retention: Perceptions of child welfare supervisors. International Journal of Continuing Social Work Education, 6, (3), 931

Shahzadi, I., Javed, A, Pirzada, S.S, \& Nasreen S,K.f. (2014). Impact of Employee Motivation on 
Employee Performance. European Journal of Business and Management. 40, (5), 678

Shakeel S,L.S. (2015). Impact of Training and Development on Employee performance: A Case of Banking Sector of Pakistan. Journal of Resources Development and Managemen, 14, 22-29.

Siagian, S.P. (2003). Teori dan Praktek Kepemimpinan. Rineka Cipta.

Sudarmanto. (2009). Kinerja dan Pengembangan Kompetensi Sumber Daya Manusia. Pustaka Pelajar.

Sultana, A., Irum, S., Ahmed, K., \& Mehmood, N. (2012). Impact of training on employee performance: A study of telecommunication sector in Pakistan. Interdisciplinary Journal of Contemporary Research in Business, 4, (6), 86

Suryadi. (2010). Analisis Peranan Leadership dan Budaya Organisasi Terhadap Kinerja Pegawai. Junal Manajerial, 8, (1), 1-9
Tabassi, A.A., Ramli, M. \& Abu Bakar, A. . (2011). Training, motivation and team improvement: The case of construction firms. African Journal of Business Management, 5, (14), 106

Tangkisian, H.N.S. (2005). Manajemen Publik. PT Gramedia Pustaka.

Veitzal R, \& B. (2005). Performance Appraisal : Sistem yang tepat untuk menilai kinerja karyawan dan meningkatkan daya saing perusahaan. Bandung: PT Raja Grafindo Persada.

Wance, M. (2019). Evaluasi Pelayanan Kinerja Pada Badan Kesatuan Bangsa Dan Politik Kota Ternate Tahun 2017. 46-62. https://doi.org/ https://doi.org/10.26618/kjap.v5i1.1945

Wargadinata, E (2017). Kualitas Pengukuran Kinerja Organisasi Publik. Sosiohumaniora, 19, (2), 86-94

Yunus, E. (2012). Pengaruh Kompetensi Sumber Daya Manusia terhadap Kinerja Pegawai KPPBC Tipe Madya Pabean Tanjung Perak Surabaya. Ekuitas Jurnal Ekonomi Dan Keuangan 16, (3), 368-387. 